\title{
Penerapan 5s (Seiri, Seiton, Seiso, Seiketsu, Shitsuke) untuk Reduksi Non Value Added Activity di PT X
}

\section{Dea Legina Ayu Kusumah*, Chaznin R. Muhammad}

Prodi Teknik Industri, Fakultas Teknik, Universitas Islam Bandung, Indonesia.

*dealegina@gmail.com, chaznin_crm@yahoo.co.id

\begin{abstract}
PT X is a manufacturing company in publishing, printing, security printing, and general trade. The company has several large machines to support the production process. The company also provides spare partsused for the engine repair process. The problem at the company is the high time to take and wait for spare parts that cause high downtime. The activity of taking spareparts makes time for 60 minutes and the activity of waiting for spare parts takes 2.880 minutes. The high time to take and wait is due to spare parts storage that does not separate old and new spare parts, spare parts are not arranged according to type, thereis no sign according to the type of spare parts, the contents of the storage area are notvisible, there are different spare parts in the same location, and there is no sign of spare parts stock. Taking and waiting activities are non value added activity (NVAA).Therefore, there needs to be improvements to reduce non value added activity. Improvement are made with the application of the $5 \mathrm{~S}$ (seiri, seiton, seiso, seiketsu, and shitsuke). The $5 \mathrm{~S}$ method can be used to rearrange spare parts storage in the company, so that spare parts are easy to find and availability can be known. After repairs, there was a decrease in the time to take spare parts by $95.37 \%$ and a decrease in spare parts waiting time by $100 \%$.
\end{abstract}

Keywords: Sparepart, Non Value Added Activity, 5S.

\begin{abstract}
Abstrak. PT X merupakan perusahaan manufaktur yang bergerakpada bidang penerbitan, percetakan, security printing, dan perdagangan umum. Perusahaan ini memiliki beberapa mesin besar untuk menunjang proses produksi. Perusahaan juga menyediakan sparepart yang digunakan untuk proses perbaikan mesin. Permasalahan yang dihadapi PT X adalah tingginya waktu mengambil dan menunggu sparepart yang menyebabkan downtime tinggi. Aktivitas mengambil sparepart membuatuhkan waktu selama 60 menit dan aktivitas menunggu sparepart membutuhkan waktu selama 2.880 menit. Tingginya waktu mengambil dan menunggu disebabkan karena penyimpanan sparepart yang tidak memisahkan sparepart lama dan baru, sparepart tidak disusun sesuai jenis, tidak ada tanda sesuaijenis sparepart, isi dari tempat penyimpanan tidak terlihat, terdapat sparepart berbeda pada lokasi yang sama, dan tidak ada tanda stok sparepart. Aktivitas mengambil dan aktivitas menunggu merupakan aktivitas yang tidak memberikan nilai tambah. Oleh karena itu perlu adanya perbaikan untuk mereduksi aktivitas yang tidakmemberikan nilai tambah. Upaya perbaikan dilakukan dengan penerapan 5S (seiri, seiton, seiso, seiketsu, and shitsuke). Metode 5S dapat digunakan untuk menata ulang penyimpanan sparepart di perusahaan, sehingga sparepart mudah ditemukan dan ketersediaan sparepart juga dapat diketahui. Setelah dilakukan perbaikan, terjadi penurunan waktu mengambil sparepart sebesar $95,37 \%$ dan penurunan waktu menunggu sparepart sebesar $100 \%$.
\end{abstract}

Kata Kunci: Sparepart, Aktivitas Yang Tidak Memberikan Nilai Tambah, 5S. 


\section{A. Pendahuluan}

PT X memiliki beberapa mesin besar untuk menunjang proses produksinya. Mesin-mesin tersebut harus mendapatkan perawatan agar selalu dalam keadaan baikdan bisa digunakan kapanpun ketika ada order. PT X menyediakan sparepart yang akan digunakan pada mesin. Sparepart yang ada di perusahaan yaitu Bearing, V Belt, pneumatic, Relay, rubber cutting, folding blade, tucker blade, dan cutting knife. Berikut inimerupakan data downtime yang dapat dilihat pada Tabel 1. Data ini diperoleh dari bulan Januari sampai dengan bulan Desember tahun 2020 dalam 2 shift kerja atau sama dengan 16 jam per hari.

Tabel 1. Data Downtime (Mengambil, Menunggu dan Perawatan)

\begin{tabular}{|c|c|c|c|c|c|c|}
\hline No & $\begin{array}{c}\text { Tanggal } \\
\text { Mulai }\end{array}$ & $\begin{array}{l}\text { Tanggal } \\
\text { Selesai }\end{array}$ & Bagian & Mesin & $\begin{array}{c}\text { Interval } \\
\text { Downtime }\end{array}$ & $\begin{array}{c}\text { Downtime } \\
\text { (Jam) }\end{array}$ \\
\hline 1 & $08 / 01 / 2020$ & $09 / 01 / 2020$ & Finishing & Polar & 1 hari & 16,00 \\
\hline 2 & $09 / 01 / 2020$ & $10 / 01 / 2020$ & Finishing & Wohlenberg & 1 hari & 16,00 \\
\hline 3 & $13 / 01 / 2020$ & $13 / 01 / 2020$ & Finishing & W3S1 & - & 0,42 \\
\hline 4 & $15 / 01 / 2020$ & $15 / 01 / 2020$ & Cetak & Solna 380A & - & 0,42 \\
\hline 5 & $15 / 01 / 2020$ & $15 / 01 / 2020$ & Finishing & Sthal 88 & - & 0,42 \\
\hline 6 & $15 / 01 / 2020$ & $17 / 01 / 2020$ & Cetak & $\begin{array}{c}\text { Inkpum } \\
\text { Solna }\end{array}$ & 2 hari & 32,00 \\
\hline 7 & $17 / 01 / 2020$ & $17 / 01 / 2020$ & Finishing & W3S1 & - & 0,42 \\
\hline 8 & $03 / 03 / 2020$ & $03 / 03 / 2020$ & Finishing & Wohlenberg & - & 0,42 \\
\hline 9 & $16 / 03 / 2020$ & $16 / 03 / 2020$ & Cetak & $\begin{array}{l}\text { Plate Bending } \\
\text { Mitsubishi }\end{array}$ & - & 0,42 \\
\hline 10 & $02 / 04 / 2020$ & $07 / 04 / 2020$ & Cetak & Vernish & 5 hari & 80,00 \\
\hline 11 & $13 / 04 / 2020$ & $14 / 04 / 2020$ & Cetak & Goss & 1 hari & 16,00 \\
\hline 12 & $13 / 04 / 2020$ & $13 / 04 / 2020$ & Cetak & Solna 380A & - & 0,42 \\
\hline 13 & $13 / 04 / 2020$ & $13 / 04 / 2020$ & Cetak & Solna 380B & - & 0,42 \\
\hline 14 & $10 / 03 / 2020$ & $15 / 04 / 2020$ & Cetak & Solna 301 & 5 hari & 80,00 \\
\hline 15 & $25 / 04 / 2020$ & $26 / 04 / 2020$ & Cetak & Solna 380B & 1 hari & 16,00 \\
\hline 16 & $28 / 04 / 2020$ & $30 / 04 / 2020$ & Cetak & Solna 301 & 2 hari & 32,00 \\
\hline 17 & $02 / 05 / 2020$ & $02 / 05 / 2020$ & Cetak & Goss & $06.20-14.00$ & 6,67 \\
\hline 18 & $03 / 05 / 2020$ & $03 / 05 / 2020$ & Cetak & Solna 380B & $07.40-10.00$ & 2,33 \\
\hline 19 & $03 / 05 / 2020$ & $03 / 05 / 2020$ & Cetak & Solna 301 & $10.50-13.50$ & 2,00 \\
\hline 20 & $04 / 05 / 2020$ & $04 / 05 / 2020$ & Cetak & Solna 301 & $06.55-08.20$ & 1,42 \\
\hline 21 & $28 / 04 / 2020$ & $08 / 05 / 2020$ & Cetak & Solna 380B & 10 hari & 160,00 \\
\hline 22 & $09 / 05 / 2020$ & $09 / 05 / 2020$ & Finishing & Rosback 3 & - & 0,42 \\
\hline 23 & $09 / 05 / 2020$ & $09 / 05 / 2020$ & Finishing & Sthal 78 & - & 0,42 \\
\hline 24 & $09 / 05 / 2020$ & $09 / 05 / 2020$ & Finishing & Sthal 88 & - & 0,42 \\
\hline 25 & $13 / 05 / 2020$ & $13 / 05 / 2020$ & Cetak & Solna 380A & $07.30-11.00$ & 3,50 \\
\hline 26 & $20 / 05 / 2020$ & $20 / 05 / 2020$ & Cetak & Harris & $05.30-14.50$ & 9,33 \\
\hline 27 & $23 / 05 / 2020$ & $23 / 05 / 2020$ & Cetak & Solna 301 & $05.30-09.45$ & 3,25 \\
\hline 28 & $22 / 05 / 2020$ & $22 / 05 / 2020$ & Cetak & Vernish & $07.00-10.00$ & 3,00 \\
\hline 29 & $22 / 05 / 2020$ & $22 / 05 / 2020$ & Cetak & Solna 301 & $09.40-14.30$ & 3,83 \\
\hline 30 & $04 / 06 / 2020$ & $04 / 06 / 2020$ & Cetak & Goss & - & 0,42 \\
\hline 31 & $04 / 06 / 2020$ & $05 / 06 / 2020$ & Finishing & MCS & 1 hari & 16,00 \\
\hline 32 & $05 / 06 / 2020$ & $06 / 06 / 2020$ & Cetak & Solna 301 & 1 hari & 16,00 \\
\hline 33 & $10 / 06 / 2020$ & $10 / 06 / 2020$ & Cetak & Solna 301 & - & 0,42 \\
\hline 34 & $08 / 06 / 2020$ & $10 / 06 / 2020$ & Cetak & Goss & 2 hari & 32,00 \\
\hline 35 & $11 / 06 / 2020$ & $11 / 06 / 2020$ & Cetak & Solna 301 & - & 0,42 \\
\hline 36 & $12 / 06 / 2020$ & $13 / 06 / 2020$ & Cetak & Solna 301 & 1 hari & 16,00 \\
\hline 37 & $14 / 06 / 2020$ & $16 / 06 / 2020$ & Cetak & Harris & 2 hari & 32,00 \\
\hline 38 & $28 / 06 / 2020$ & $29 / 06 / 2020$ & Cetak & Solna 301 & $19.55-03.35$ & 6,67 \\
\hline 39 & $29 / 06 / 2020$ & $29 / 06 / 2020$ & Cetak & Solna 380B & $23.20-04.30$ & 5,17 \\
\hline
\end{tabular}


Tabel 1. Data Downtime (Mengambil, Menunggu, dan Perawatan) (Lanjutan)

\begin{tabular}{|c|c|c|c|c|c|c|}
\hline No & $\begin{array}{c}\text { Tanggal } \\
\text { Mulai }\end{array}$ & $\begin{array}{c}\text { Tanggal } \\
\text { Selesai }\end{array}$ & Bagian & Mesin & $\begin{array}{c}\text { Interval } \\
\text { Downtime }\end{array}$ & $\begin{array}{c}\text { Downtime } \\
\text { (Jam) }\end{array}$ \\
\hline 40 & $10 / 05 / 2020$ & $29 / 06 / 2020$ & Cetak & Solna 380A & 50 hari & 800,00 \\
\hline 41 & 07/07/2020 & 07/07/2020 & Cetak & $\begin{array}{c}\text { Inkpum } \\
\text { Goss/Harris }\end{array}$ & - & 0,42 \\
\hline 42 & $07 / 07 / 2020$ & $07 / 07 / 2020$ & Cetak & Goss & - & 0,42 \\
\hline 43 & $09 / 07 / 2020$ & $09 / 07 / 2020$ & Cetak & Harris & - & 0,42 \\
\hline 44 & $10 / 07 / 2020$ & $10 / 07 / 2020$ & Finishing & Wohlenberg & - & 0,42 \\
\hline 45 & $20 / 07 / 2020$ & $22 / 07 / 2020$ & Cetak & Solna 380A & 2 hari & 32,00 \\
\hline 46 & $08 / 07 / 2020$ & $23 / 07 / 2020$ & Cetak & Goss & 15 hari & 240,00 \\
\hline 47 & $24 / 07 / 2020$ & 24/07/2020 & Logistik & $\begin{array}{c}\text { Straping } \\
\text { band }\end{array}$ & - & 0,42 \\
\hline 48 & $24 / 07 / 2020$ & $27 / 07 / 2020$ & Cetak & Solna 380A & 3 hari & 48,00 \\
\hline 49 & $27 / 07 / 2020$ & $29 / 07 / 2020$ & Cetak & Vernish & 2 hari & 32,00 \\
\hline 50 & $04 / 08 / 2020$ & $04 / 08 / 2020$ & Finishing & Wohlenberg & $11.00-15.30$ & 3,50 \\
\hline 51 & $07 / 08 / 2020$ & $07 / 08 / 2020$ & Cetak & Solna 380A & - & 0,42 \\
\hline 52 & $13 / 08 / 2020$ & $13 / 08 / 2020$ & Cetak & Mitsubishi & - & 0,42 \\
\hline 53 & $18 / 08 / 2020$ & $18 / 08 / 2020$ & Cetak & Mitsubishi & - & 0,42 \\
\hline 54 & $18 / 08 / 2020$ & $18 / 08 / 2020$ & Cetak & Solna 380B & $13.40-21.05$ & 7,41 \\
\hline 55 & 19/08/2020 & 19/08/2020 & Cetak & Harris & - & 0,42 \\
\hline 56 & $19 / 08 / 2020$ & $19 / 08 / 2020$ & Cetak & Solna 301 & - & 0,42 \\
\hline 57 & $19 / 08 / 2020$ & $19 / 08 / 2020$ & Cetak & Goss & - & 0,42 \\
\hline 58 & $22 / 07 / 2020$ & $22 / 08 / 2020$ & Cetak & Solna 380B & - & 0,42 \\
\hline 59 & $25 / 08 / 2020$ & $25 / 08 / 2020$ & Cetak & Solna 380B & - & 0,42 \\
\hline 60 & $27 / 08 / 2020$ & $28 / 08 / 2020$ & Cetak & Solna 301 & $21.45-02.30$ & 3,75 \\
\hline 61 & $28 / 08 / 2020$ & $28 / 08 / 2020$ & Finishing & Sthal 78 & - & 0,42 \\
\hline 62 & $28 / 08 / 2020$ & $01 / 09 / 2020$ & Finishing & Wohlenberg & 2 hari & 32,00 \\
\hline 63 & $31 / 08 / 2020$ & $01 / 09 / 2020$ & Cetak & Solna 301 & 1 hari & 16,00 \\
\hline 64 & $24 / 08 / 2020$ & $02 / 09 / 2020$ & Cetak & Solna 380A & 7 hari & 112,00 \\
\hline 65 & $02 / 09 / 2020$ & $02 / 09 / 2020$ & Cetak & Solna 301 & - & 0,42 \\
\hline 66 & $24 / 09 / 2020$ & $24 / 09 / 2020$ & Cetak & Goss & $11.12-14.50$ & 2,63 \\
\hline 67 & $24 / 09 / 2020$ & $24 / 09 / 2020$ & Cetak & Solna 301 & $08.00-09.30$ & 1,50 \\
\hline 68 & $05 / 10 / 2020$ & $05 / 10 / 2020$ & Cetak & Solna 380B & $08.00-10.00$ & 2,00 \\
\hline 69 & $07 / 10 / 2020$ & $07 / 10 / 2020$ & Cetak & Solna 301 & $14.00-15.00$ & 1,00 \\
\hline 70 & $07 / 10 / 2020$ & $07 / 10 / 2020$ & Cetak & Solna 301 & $16.00-18.30$ & 2,50 \\
\hline 71 & $07 / 10 / 2020$ & $07 / 10 / 2020$ & Cetak & Solna 301 & $19.30-22.00$ & 2,50 \\
\hline 72 & $07 / 10 / 2020$ & $07 / 10 / 2020$ & Cetak & Solna 301 & $02.15-02.45$ & 0,50 \\
\hline 73 & $09 / 10 / 2020$ & $09 / 10 / 2020$ & Finishing & Sthal 78 & - & 0,42 \\
\hline 74 & 09/10/2020 & $09 / 10 / 2020$ & Finishing & Sthal 88 & - & 0,42 \\
\hline 75 & $06 / 11 / 2020$ & $06 / 11 / 2020$ & Cetak & Solna 380B & - & 0,42 \\
\hline 76 & $06 / 11 / 2020$ & $06 / 11 / 2020$ & Cetak & Pond 2 & - & 0,42 \\
\hline 77 & $06 / 11 / 2020$ & $10 / 11 / 2020$ & Cetak & Rolland 200 & 4 hari & 64,00 \\
\hline 78 & $16 / 11 / 2020$ & $17 / 11 / 2020$ & Finishing & Wohlenberg & 1 hari & 16,00 \\
\hline 79 & $10 / 12 / 2020$ & $10 / 12 / 2020$ & Cetak & $\begin{array}{c}\text { Compressor } \\
\text { central BSD } \\
72\end{array}$ & - & 0,42 \\
\hline 80 & $14 / 12 / 2020$ & $15 / 12 / 2020$ & Finishing & Sthal 88 & 1 hari & 16,00 \\
\hline \multicolumn{6}{|c|}{ Total } & $2.056,74$ \\
\hline
\end{tabular}

Sumber: PT X (2020) 
Terdapat waktu downtime yang melebihi waktu 1 shift kerja dan total waktu downtime pada 8 Januari 2020 sampai dengan 15 Desember 2020 ini adalah 2.056,74 jam. Waktu downtime yang tinggi menjadi masalah bagi perusahaan karena dapat menghambat proses produksi. Data downtime terdiri dari waktu mengambil sparepart, menunggu sparepart, dan perawatan mesin. Berdasarkan hasil wawancara dengan manajer teknisi dapat diketahui rata-rata waktu untuk mengambil sparepart dan menunggu sparepart yang dapat dilihat pada Tabel 2.

Tabel 2. Rata-Rata Waktu Mengambil dan Waktu Menunggu

\begin{tabular}{|l|l|}
\hline Rata-rata waktu mengambil sparepart & 1 jam \\
\hline Rata-rata waktu menunggu sparepart & $1-2$ hari \\
\hline
\end{tabular}

Waktu untuk mengambil sparepart dipengaruhi oleh lokasi penyimpanan sparepart. Jika lokasi penyimpanan mudah ditemukan dan sparepart tidak tercampur, maka waktu mengambil sparepart akan lebih cepat. Aktivitas mengambil sparepart terdiri dari elemen gerakan mencari, menjangkau, memegang, dan membawa. Elemen gerakan mencari, menjangkau, dan membawa termasuk kedalam pemborosan gerakan (waste of motion). Elemen gerakan membawa juga termasuk kedalam pemborosan transportasi (waste of transportation). Pengambilan sparepart selama 1 jam disebabkan karena sistem penyimpanan sparepart yang tidak teratur. Ketidakteraturan penyimpanan sparepart menyebabkan teknisi kesulitan untuk menemukan sparepart dan harus mengulangi elemen gerakan mencari, menjangkau, memegang, dan membawa hingga sparepart ditemukan. Namun, jika sparepart tidak ditemukan maka akan dilakukan pemesanan sparepart. Dalam hal ini, melakukan pemesanan sparepart yang dibutuhkan dapat membuat mesin menunggu, sehingga terjadi pemborosan menunggu (waste of waiting). Waktu menunggu sparepart terjadi karena stok sparepart tidak diketahui.

Berdasarkan latar belakang yang telah diuraikan, maka perumusan masalah dalam penelitian ini sebagai berikut: "Apa saja non value added activity pada sistem penyimpanan sparepart di PT X?", "Bagaimana cara mengatasi non value added activity pada sistem penyimpanan sparepart di PT X?". Selanjutnya, tujuan dalam penelitian ini diuraikan dalam pokok-pokok sebagai berikut.

1. Mengidentifikasi non value added activity pada sistem penyimpanan sparepart di PT X saat ini.

2. Mengusulkan langkah perbaikan untuk mengatasi non value added activity pada sistem penyimpanan sparepart di PT X.

\section{B. Metodologi Penelitian}

Penelitian diawali dengan melakukan identifikasi perusahaan untuk mengetahui permasalahan yang ada di perusahaan. Setelah mengetahui permasalahan di perusahaan, dilakukan perumusan masalah, penetapan tujuan, penentuan batasan masalah, studi pustaka, pengumpulan data, dan pengolahan data.

Pemborosan atau waste adalah setiap aktivitas kerja yang tidak memberikan nilai tambah (non value added activity). Taiichi Ohno mengidentifikasi tujuh bentuk pemborosan (waste) yaitu waste of overproduction (pemborosan produksi berlebih), waste of waiting (pemborosan menunggu), waste of transportation (pemborosan transportasi), waste of overprocessing (pemborosan pemrosesan berlebih), waste of inventory (pemborosan persediaan), waste of motion (pemborosan gerak), dan waste of defect (pemborosan cacat) (Carreira, 2005).

Pemborosan dapat dianalisis dengan menggunakan peta aliran proses. Peta aliran proses menunjukkan urutan operasi, pemeriksaan, transportasi, menunggu, dan penyimpanan selama suatu proses berlangsung. Terdapat beberapa informasi pada peta aliran proses yang dibutuhkan untuk menganalisis waktu (jam atau menit) dan jarak perpindahan (meter) (Sutalaksana, Anggawisastra dan Tjakraatmadja, 2006). Selain melakukan analisis pemborosan, dilakukan juga perhitungan persentase penerapan $5 \mathrm{~S}$ sebelum dan sesudah perbaikan di perusahaan dengan menggunakan checklist 5S. Checklist $5 \mathrm{~S}$ digunakan sebagai parameter penilaian pada implementasi 5S. Checklist 5S terdiri dari pertanyaan untuk setiap aktivitas $5 \mathrm{~S}$ yang dilakukan (Imai, 2016). Setelah diketahui pemborosan apa yang terjadi di perusahaan, maka dilakukan perbaikan dengan konsep 5S. $5 \mathrm{~S}$ adalah metode pengaturan lingkungan kerja yang berusaha menghilangkan pemborosan (waste) (Osada, 1995). Selain itu, konsep 5S ini juga membahas mengenai 
checklist 5 S yang dapat digunakan untuk penilaian implementasi $5 \mathrm{~S}$.

1. Seiri (Pemilahan): aktivitas memisahkan barang yang diperlukan dengan barang yang tidak diperlukan.

2. Seiton (penataan): suatu kegiatan untuk menentukan tata letak penyimpanan barang, sehingga barang tertata rapi dan pekerja dapat menemukan barang yang diperlukan dengan mudah.

3. Seiso (pembersihan): kegiatan untuk menghilangkan sampah dan barang asing yang ada dilingkungan kerja, sehingga lingkungan kerja menjadi lebih bersih.

4. Seiketsu (pemantapan): kegiatan yang dilakukan terus menerus dan berulang untuk memelihara seiri, seiton, dan seiso sehingga hasil yang telah dicapai pada 3S dapat dipertahankan.

5. Shitsuke (pembiasaan): kegiatan untuk melakukan suatu aktivitas yang benar menjadi suatu kebiasaan.

Aktivitas pertama 5S yaitu seiri menggunakan konsep red tagging untuk menunjukkan beberapa informasi status suatu barang yang mungkin dibutuhkan atau tidak dibutuhkan (Visco, 2016). Selain itu, aktivitas seiketsu juga menggunakan konsep manajemen visual untuk menunjukkan informasi tentang proses produksi dan kegiatan sehari-hari mendasar yang tersedia secara visual. Teknik ini dapat memberikan informasi untuk semua orang yang terlibat dalam proses, sehingga setiap orang memiliki tanggung jawab pada setiap proses yang dilakukan. Manajemen visual berfungsi untuk mempercepat penyebaran informasi dan memudahkan orangorang untuk memahami informasi tersebut. (Matias dan Idoipe, 2013).

Penerapan konsep 5S tidak diimplementasikan di perusahaan. Namun, diharapkan dapat mereduksi pemborosan atau aktivitas yang tidak memberikan nilai tambah yang ada di perusahaan. Waktu aktivitas mengambil dan menunggu setelah perbaikan dapat diukur dengan menggunakan Measurement Time Method (MTM). MTM merupakan metode pengukuran waktu secara tidak langsung yang dapat dilakukan tanpa berada di tempat pekerjaan dijalankan. Tetapi dengan membaca tabel yang telah disediakan. Pengukuran ini dapat dilakukan jika mengetahui elemen gerakan. Setiap elemen gerakan ditentukan berdasarkan kelas-kelas yang menunjukkan kondisi setiap elemen gerakan. Satuan waktu MTM adalah Time Measurement Unit (TMU), dimana 1 TMU sama dengan 0.0006 menit (Sutalaksana, Anggawisastra, dan Tjakraatmadja, 2006).

\section{Hasil Penelitian dan Pembahasan}

\section{Analisis NVAA dengan Menggunakan Flow Prosess Chart}

\begin{tabular}{|c|c|c|c|c|c|c|c|c|c|c|}
\hline \multicolumn{11}{|c|}{$\begin{array}{l}\text { PETA ALIRAN PROSES } \\
\end{array}$} \\
\hline \multicolumn{7}{|c|}{ RINGKASAN } & \multirow{2}{*}{\multicolumn{2}{|c|}{ KOMPONEN }} & \multirow{2}{*}{\multicolumn{2}{|c|}{ SPAREPART }} \\
\hline \multirow[b]{2}{*}{ KEGIATAN } & \multicolumn{2}{|c|}{ SEKARANG } & \multicolumn{2}{|c|}{ USULAN } & \multicolumn{2}{|c|}{ BEDA } & & & & \\
\hline & JML & WKT & & WKT & JML & WKT & \multirow{2}{*}{\multicolumn{2}{|c|}{\begin{tabular}{|c|} 
PEKERJAAN \\
NOMOR PETA
\end{tabular}}} & \multicolumn{2}{|c|}{\begin{tabular}{|l} 
Pengadaan Sparepart \\
\end{tabular}} \\
\hline O OPERASI & 7 & 2902 & & & & & & & \multicolumn{2}{|c|}{1} \\
\hline PEMERIKSAAN & - & 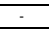 & & & & & \multirow{2}{*}{\multicolumn{2}{|c|}{$\begin{array}{|ll|}\text { ORANG } \quad \square \\
\text { SEKARANGE }\end{array}$}} & \multicolumn{2}{|c|}{ BAHAN } \\
\hline$\Rightarrow$ TRANSPORTASI & 1 & 5 & & & & & & & \multicolumn{2}{|c|}{ USULA® } \\
\hline \begin{tabular}{|l} 
D MENUNGGU \\
\end{tabular} & & & & & & & \multicolumn{2}{|c|}{ SEKARANG! } & \multirow{2}{*}{\multicolumn{2}{|c|}{\begin{tabular}{|c|} 
Dea Legina AK \\
09 Juli 2021 \\
\end{tabular}}} \\
\hline$\nabla$ PEYIMPANAN & 1 & & & & & & \multicolumn{2}{|c|}{\begin{tabular}{|l|} 
TANGGAL \\
\end{tabular}} & & \\
\hline JUMLAH & & 2907 & & & & & & \multirow{3}{*}{$\begin{array}{r}\text { JARAK } \\
(\mathrm{CM})\end{array}$} & \multirow[b]{3}{*}{ JUMLAH } & \multirow{3}{*}{$\begin{array}{l}\text { WAKTU } \\
\text { (MENIT) }\end{array}$} \\
\hline \multirow{2}{*}{\multicolumn{3}{|c|}{ URAIAN KEGIATAN }} & \multicolumn{5}{|c|}{ LAMBANG } & & & \\
\hline & & & 0 & $\square$ & $\Rightarrow$ & D & $\nabla$ & & & \\
\hline \multicolumn{3}{|c|}{ Melapor kebutuhan sparepart } & - & & & & & $\cdot$ & 1 & 5 \\
\hline \multicolumn{3}{|c|}{ Membuat surat pengajuan sparepart } & 9 & & & & & - & 1 & 5 \\
\hline \multicolumn{3}{|c|}{ Surat pengajuan sparepart disetujui } & 0 & & & & & - & 1 & 5 \\
\hline \multicolumn{3}{|c|}{ Mengajukan surat pembelian sparepart } & 0 & & & & & - & 1 & 5 \\
\hline \multicolumn{3}{|c|}{ Melakukan pembelian sparepart } & 9 & & & & & - & 1 & 2880 \\
\hline \multicolumn{3}{|c|}{ Sparepart tiba di gudang bahan baku } & 8 & & & & & - & 1 & - \\
\hline \multicolumn{3}{|c|}{ Melaporkan kedatangan sparepart } & 2 & & & & & - & 1 & 2 \\
\hline \multicolumn{3}{|c|}{ Sparepart dibawa ke ruang manajer } & & & a & & & 15000 & 1 & 5 \\
\hline \multicolumn{3}{|c|}{$\begin{array}{l}\text { Sparepart disimpan di tempat } \\
\text { penyimpanan }\end{array}$} & & & & & 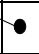 & - & 1 & $\cdot$ \\
\hline
\end{tabular}

(a)

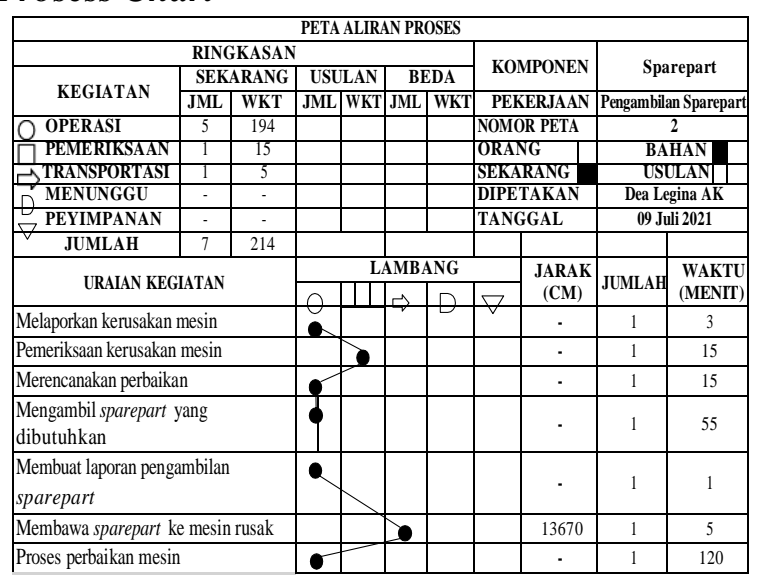

(b)

Gambar 1. Peta Aliran Proses (a) Pengadaan Sparepart dan (b) Pengambilan Sparepart

Analisis NVAA dilakukan dengan menggunakan peta aliran proses. Data yang digunakan yaitu proses bisnis pengadaan sparepart dan proses bisnis penggunaan sparepart. Berdasarkan hasil pengolahan data, terdapat NVAA pada proses pengadaan sparepart dan pengambilan sparepart. NVAA yang terjadi yaitu pemborosan menunggu (waste of waiting) dan pemborosan gerakan (waste of motion). Pemborosan menunggu terjadi karena ketika sparepart dibutuhkan, 
sparepart tidak tersedia di gudang penyimpanan sparepart. Hal ini menyebabkan mesin harus menunggu selama 2880 menit, karena sparepart harus di pesan. Waktu yang tinggi ini menimbulkan pemborosan dan menyebabkan downtime menjadi tinggi. Pemborosan gerakan terjadi karena penyimpanan sparepart yang tidak teratur. Sehingga teknisi harus melakukan gerakan mencari, menjangkau, memegang, dan membawa secara berulang sampai sparepart ditemukan. Waktu yang dibutuhkan untuk melakukan elemen gerakan ini yaitu 60 menit. Selain NVAA, pada perusahaan ini juga terdapat necessary non value added activity (NNVAA) berupa transportasi. Aktivitas transportasi termasuk ke dalam necessary non value added activity karena aktivitas transportasi merupakan aktivitas yang tidak dapat dihilangkan dan perlu dilakukan, namun tidak memberikan nilai tambah.

\section{Kondisi Penyimpanan Sparepart Sebelum Perbaikan}

Persentase penerapan 5S sebelum perbaikan dapat diketahui dengan checklist 5S. Penilai $5 \mathrm{~S}$ dilakukan dengan melihat skor total keseluruhan. Skor total keseluruhan program $5 \mathrm{~S}$ dapat dihitung dengan menggunakan formulir skor program $5 \mathrm{~S}$ yang dapat dilihat pada Tabel 3.

Tabel 3. Skor Program 5S Sebelum Perbaikan

\begin{tabular}{|c|c|c|c|c|}
\hline & $\begin{array}{l}\text { Pemberian skor untuk setiap pernyataan berdasarkan aplikasi: } 0-20 \%= \\
\text { skor } 1,21 \%-40 \%=\text { skor } 2,41 \%-60 \%=\text { skor } 3,61 \%-80 \%=\text { skor } 4\end{array}$ & \multicolumn{3}{|c|}{ Skor } \\
\hline No & Pernyataan & 1 & \begin{tabular}{l|l|l}
2 & $\mathbf{3}$ & $\mathbf{4}$ \\
\end{tabular} & 5 \\
\hline 1 & $\begin{array}{l}\text { Semua orang telah memberikan kontribusi terhadap proses red tagging } \\
\text { untuk menyingkirkan item-item yang tidak diperlukan }\end{array}$ & $\checkmark$ & & \\
\hline 2 & Semua orang telah mengikuti prosedur untuk melakukan proses $3 \mathrm{~S}$ & $\checkmark$ & & \\
\hline 3 & $\begin{array}{l}\text { Semua mesin dan peralatan ditempatkan atau disimpan pada tempat } \\
\text { yang telah ditentukan. Telah ada penunjukan personil secara formal dari } \\
\text { manajemen untuk bertanggung jawab memelihara mesin, peralatan, dan } \\
\text { tempat kerja }\end{array}$ & & & \\
\hline 4 & $\begin{array}{l}\text { Semua mesin, peralatan, dan tempat kerja tampak bersih dan terpelihara } \\
\text { dengan sangat baik dan teratur }\end{array}$ & & $\checkmark$ & \\
\hline 5 & $\begin{array}{l}\text { Terdapat } 5 \mathrm{~S} \text { visual board, poster-poster, dan bentuk-bentuk visual } \\
\text { lainnya yang memungkinkan semua orang mengetahui dan mengerti } \\
\text { tentang } 5 \mathrm{~S} \text { dalam organisasi }\end{array}$ & $\checkmark$ & & \\
\hline 6 & $\begin{array}{l}\text { Terdapat prosedur dan instruksi kerja tentang } 5 \mathrm{~S} \text { yang diperbaharui } \\
\text { secara berkala }\end{array}$ & $\checkmark$ & & \\
\hline 7 & $\begin{array}{l}\text { Semua karyawan dan manajemen telah memperoleh pelatihan secara } \\
\text { formal tentang } 5 \mathrm{~S} \text { agar memahami tentang prinsip-prinsip } 5 \mathrm{~S}\end{array}$ & $\checkmark$ & & \\
\hline 8 & $\begin{array}{l}\text { Terdapat sistem penghargaan dan pengakuan yang berlaku secara } \\
\text { formal sebagai alat motivasi dalam implementasi } 5 \mathrm{~S}\end{array}$ & $\checkmark$ & & \\
\hline 9 & $\begin{array}{l}\text { Terdapat sistem audit } 5 \mathrm{~S} \text { yang dilakukan secara berkala. Skor audit } \\
\text { dikomunikasikan secara visual melalui } 5 \mathrm{~S} \text { visual board. Terdapat } \\
\text { bagian audit } 5 \mathrm{~S} \text { yang bertanggung jawab secara formal dalam organisasi }\end{array}$ & $\checkmark$ & & \\
\hline & SKOR TOTAL & & 11 & \\
\hline & Maksimum Skor Total $=45$ & & Skor 5S & \\
\hline & SKOR Program 5S $(\%)=(N / 45) \times 100$ & & $24 \%$ & \\
\hline & $\begin{array}{l}\text { eria Evaluasi Program 5S: } 0-20 \%=\text { Sangat Buruk, } 21 \%-40 \%=\text { Buruk, } \\
41 \%-60 \%=\text { Cukup, } 61 \%-80 \%=\text { Baik, } 81 \%-100 \%=\text { Sangat Baik }\end{array}$ & & Buruk & \\
\hline
\end{tabular}

Berdasarkan hasil perhitungan pada Tabel 4.7, skor program $5 \mathrm{~S}$ pada sistem penyimpanan sparepart di PT X adalah 24\% yang dikategorikan buruk. Kategori ini merujuk pada teori dari Maasaki Imai. 


\section{Penerapan 5S}

1. Penerapan Seiri

- Melakukan pembersihan pada sparepart dan tempat penyimpanan sparepart

- Melakukan pemilahan sesuai kondisi sparepart, jenis sparepart, tipe sparepart dan frekuensi pemakaian.

- Memberi Red Tag pada sparepart yang rusak dan sparepart yang tidak digunakan lagi. Berikut ini merupakan desain red tag yang dapat dilihat pada Gambar 2.

2. Penerapan Seiton

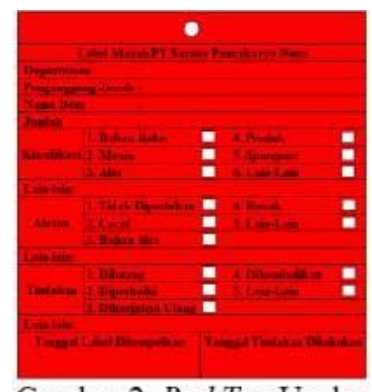

Gambar 2. Red Tag Usulan

- Melakukan penataan tempat penyimpanan dengan membuat desain tempat penyimpanan sparepart untuk setiap jenis sparepart yang dapat dilihat pada Gambar 3 sampai dengan Gambar 10.

- Melakukan penataan sparepart sesuai dengan tempat yang telah ditentukan.

- Melakukan penyimpanan dan pengambilan sparepart dengan teratur.
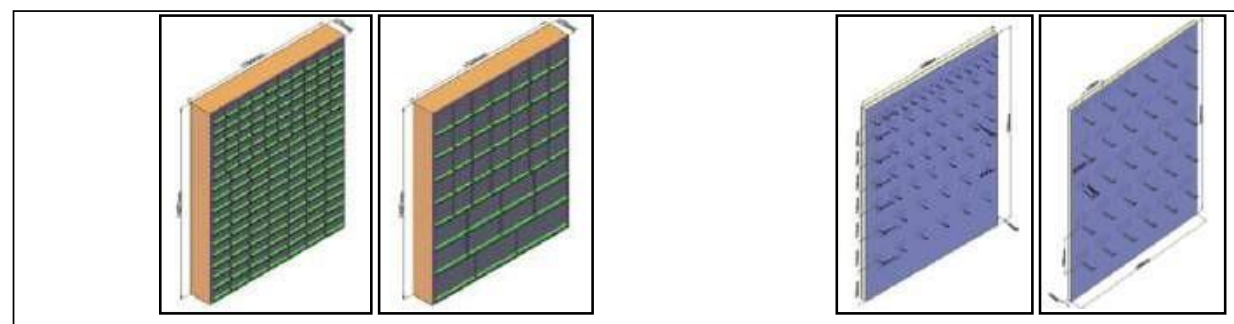

Gambar 3. Desain Penyimpanan Bearing Gambar 4. Desain Penyimpanan $V$

\begin{tabular}{|c|c|c|}
\hline $\begin{array}{c}\text { Gambar 5. Desain } \\
\text { Penyimpanan Pneumatic }\end{array}$ & $\begin{array}{c}\text { Gambar 6. Desain } \\
\text { Penyimpanan Relay }\end{array}$ \\
\hline $\begin{array}{c}\text { Gambar 8. Desain } \\
\text { Penyimpanan Folding Blade }\end{array}$ & $\begin{array}{c}\text { Cutting } \\
\text { Penyimpanan Tucker Blade }\end{array}$ \\
\hline
\end{tabular}


$150 \mid$ Dea Legina Ayu Kusumah, et

3. Penerapan Seiso

- Menanamkan rasa tanggung jawab kepada pekerja untuk menjaga kebersihan lingkungan gudang sparepart, kebersihan tempat penyimpanan, dan kebersihan sparepart.

- Melakukan pembersihan yang lebih efisien atau melakukan pekerjaan dengan tepat dan menjalankan tugas dengan cermat.

- Melakukan pembersihan dan pemeriksaan lingkungan gudang sparepart, tempat penyimpanan dan sparepart.

4. Penerapan Seiketsu

- Memelihara seiri, seiton, dan seiso sehingga menjadi aktivitas rutin yang dilakukan di tempat penyimpanan sparepart.

- Melakukan penerapan manajemen visual di perusahaan yang dapat dilihat pada Gambar 12 sampai dengan Gambar 15.

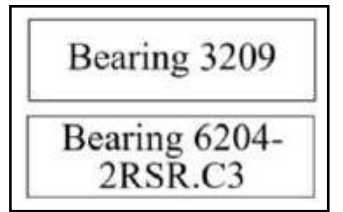

Gambar 12. Label nama sparepart

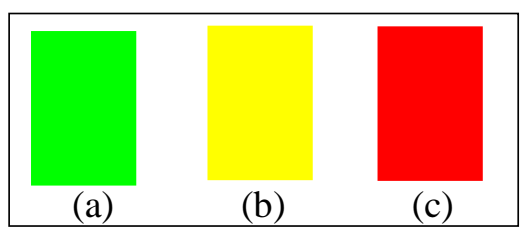

Gambar 14. Tanda (a) Stok Penuh, (b) Stok Berkurang, dan (c) Stok Habis

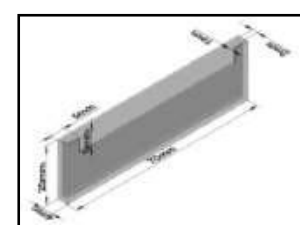

Gambar 13. Desain Penyimpanan

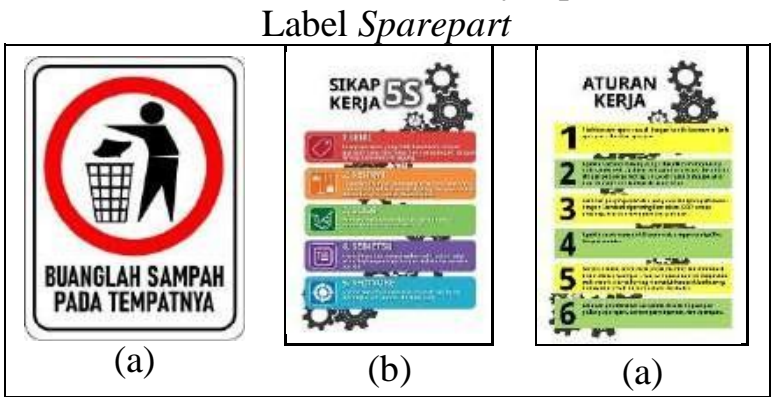

Gambar 15. Poster (a) Buang Sampah Pada Tempatnya, (b) Sikap Kerja 5S, (c) Aturan Kerja 
- Melakukan standarisasi 5S dengan membuat Standard Operating Procedure (SOP) untuk penyimpanan dan pengambilan sparepart yang dapat dilihat pada Gambar 16 dan 17.

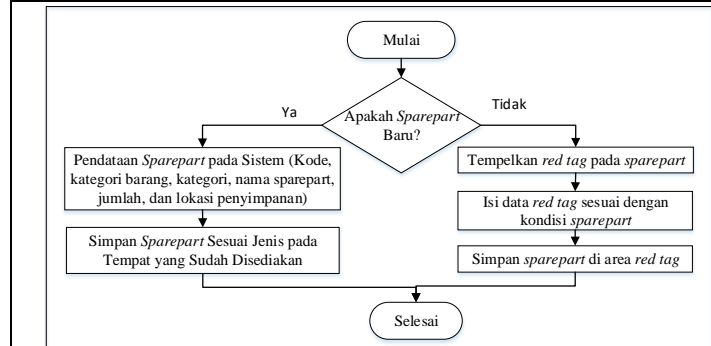

Gambar 16. SOP Penyimpanan Sparepart

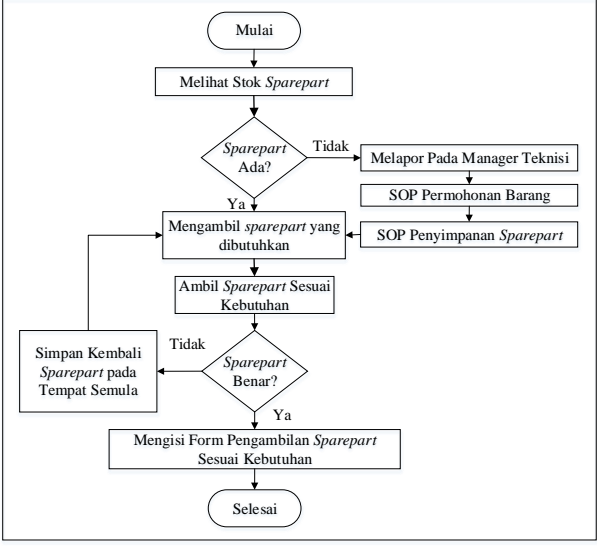

Gambar 17. SOP Pengambilan Sparepart

\section{Penerapan Shitsuke}

- Menjadikan 5S sebagai budaya kerja dengan menerapkan 5S dalam kegiatan sehari-hari di tempat kerja.

\section{Perhitungan Waktu Mengambil Sparepart}

Perhitungan waktu mengambil sparepart dilakukan dengan menggunakan metode MTM. Penentuan waktu dilakukan berdasarkan tabel MTM. Berikut ini merupakan perhitungan waktu mengambil sparepart yang dapat dilihat pada Gambar 18 sampai Gambar 28.

\begin{tabular}{|c|l|c|c|}
\hline No & \multicolumn{1}{|c|}{ Elemen Gerakan } & Notasi & $\begin{array}{c}\text { Waktu } \\
\text { (TMU) }\end{array}$ \\
\hline 1 & Gerakan mata untuk mencari sparepart & ET & 19,54 \\
\hline 2 & Menjangkau sparepart dengan jarak 30 inch & R30B & 25,8 \\
\hline 3 & Memegang sparepart & G1A & 2,00 \\
\hline 4 & Membawa sparepart dengan jarak 30 inch & M21C & 0 \\
\hline 5 & $\begin{array}{l}\text { Gerakan mata untuk melihat apakah sparepart yang } \\
\text { diambil benar }\end{array}$ & EF & 0 \\
\hline 6 & $\begin{array}{l}\text { Membawa sparepart ke mesin yang akan diperbaiki } \\
\text { dengan jarak 5382 inch dan berat sparepart kurang } \\
\text { dari 2,5 pound atau 1.133,981 gram }\end{array}$ & M5382C & $4.579,90$ \\
\hline \multicolumn{3}{|c|}{ Total } & $4.627,24$ \\
\hline
\end{tabular}

Gambar 18. Mengambil Bearing 1

\begin{tabular}{|c|l|c|c|}
\hline No & \multicolumn{1}{|c|}{ Elemen Gerakan } & Notasi & $\begin{array}{c}\text { Waktu } \\
\text { (TMU) }\end{array}$ \\
\hline 1 & Gerakan mata untuk mencari sparepart & ET & 19,76 \\
\hline 2 & Menjangkau sparepart dengan jarak 30 inch & R30C & 25,8 \\
\hline 3 & Memegang sparepart & G4A & 2,00 \\
\hline 4 & Membawa sparepart dengan jarak 30 inch & M22C & 0 \\
\hline 5 & $\begin{array}{l}\text { Gerakan mata untuk melihat apakah sparepart yang } \\
\text { diambil benar }\end{array}$ & EF & 0 \\
\hline 6 & $\begin{array}{l}\text { Membawa sparepart ke yang akan diperbaiki dengan jarak } \\
5382 \text { inch dan berat sparepart kurang dari 2,5 pound atau } \\
1.133,981 \text { gram }\end{array}$ & M5382C & 4579.9 \\
\hline \multicolumn{2}{|c|}{ Total } & $4.627,46$ \\
\hline
\end{tabular}

Gambar 20. Mengambil $V$ Belt 1

\begin{tabular}{|c|l|c|c|}
\hline No & \multicolumn{1}{|c|}{ Elemen Gerakan } & Notasi & $\begin{array}{c}\text { Waktu } \\
(\text { TMU) }\end{array}$ \\
\hline 1 & Gerakan mata untuk mencari sparepart & ET & 20,00 \\
\hline 2 & Menjangkau sparepart dengan jarak 22 inchi & R30C & 25,80 \\
\hline 3 & Memegang sparepart & G1A & 2,00 \\
\hline 4 & Membawa sparepart denga jarak 22 inch & M22C & 0 \\
\hline 5 & $\begin{array}{l}\text { Gerakan mata untuk melihat apakah sparepart yang } \\
\text { diambil benar }\end{array}$ & EF & 0 \\
\hline 6 & $\begin{array}{l}\text { Membawa sparepart ke yang akan diperbaiki dengan jarak } \\
5382 \text { inch dan berat sparepart kurang dari 2,5 pound atau } \\
1.133,981 \text { gram }\end{array}$ & M5382C & $4.579,90$ \\
\hline \multicolumn{2}{|c|}{ Total } & $4.622,90$ \\
\hline
\end{tabular}

Gambar 22. Mengambil Pneumatic 1

\begin{tabular}{|c|l|c|c}
\hline No & \multicolumn{1}{|c|}{ Elemen Gerakan } & Notasi & $\begin{array}{c}\text { Waktu } \\
\text { (TMU) }\end{array}$ \\
\hline 1 & Gerakan mata untuk mencari sparepart & ET & 20,00 \\
\hline 2 & Menjangkau sparepart dengan jarak 30 inch & R30B & 25,80 \\
\hline 3 & Memegang sparepart & G1A & 2,00 \\
\hline 4 & Membawa sparepart dengan jarak 22 inch & M22C & 0 \\
\hline 5 & $\begin{array}{l}\text { Gerakan mata untuk melihat apakah sparepart yang } \\
\text { diambil benar }\end{array}$ & EF & 0 \\
\hline \multirow{2}{*}{6} & $\begin{array}{l}\text { Membawa sparepart ke yang akan diperbaiki dengan jarak } \\
5382 \text { inch dan berat sparepart kurang dari 2,5 pound atau } \\
1.133,981 \text { gram }\end{array}$ & M5382C & $4.579,90$ \\
\hline \multicolumn{3}{|c|}{ Total } \\
\hline \multicolumn{3}{|c|}{ (2) } \\
\hline
\end{tabular}

Gambar 24. Mengambil Relay

\begin{tabular}{|c|l|c|c|}
\hline No & \multicolumn{1}{|c|}{ Elemen Gerakan } & Notasi & $\begin{array}{c}\text { Waktu } \\
\text { (TMU) }\end{array}$ \\
\hline 1 & Gerakan mata untuk mencari sparepart & ET & 19,54 \\
\hline 2 & Menjangkau sparepart dengan jarak 30 inch & R30B & 25,80 \\
\hline 3 & Memegang sparepart & G1A & 2,00 \\
\hline 4 & Membawa sparepart dengan jarak 30 inch & M21C & 0 \\
\hline 5 & $\begin{array}{l}\text { Gerakan mata untuk melihat apakah sparepart yang } \\
\text { diambil benar }\end{array}$ & $\mathrm{EF}$ & 0 \\
\hline 6 & $\begin{array}{l}\text { Membawa sparepart ke mesin yang akan diperbaiki } \\
\text { dengan jarak 5382 inch dan berat sparepart kurang } \\
\text { dari 7,5 pound atau 3.401,943 gram }\end{array}$ & M5382C & $4.582,1$ \\
\hline \multicolumn{2}{|c|}{ Total } & $4.629,44$ \\
\hline
\end{tabular}

Gambar 19. Mengambil Bearing 2

\begin{tabular}{|c|l|c|c|}
\hline No & \multicolumn{1}{|c|}{ Elemen Gerakan } & Notasi & $\begin{array}{c}\text { Waktu } \\
\text { (TMU) }\end{array}$ \\
\hline 1 & Gerakan mata untuk mencari sparepart & ET & 19.76 \\
\hline 2 & Menjangkau sparepart dengan jarak 30 inch & R30B & 25.8 \\
\hline 3 & Memegang sparepart & G1A & 2 \\
\hline 4 & Membawa sparepart dengan jarak 22 inch & M22C & 0 \\
\hline 5 & $\begin{array}{l}\text { Gerakan mata untuk melihat apakah sparepart yang } \\
\text { diambil benar }\end{array}$ & EF & 0 \\
\hline 6 & $\begin{array}{l}\text { Membawa sparepart ke mesin yang akan diperbaiki dengan } \\
\text { jarak 5382 inch dan berat sparepart kurang dari 7,5 pound } \\
\text { atau 3.401,943 gram }\end{array}$ & M5382C & $4.582,10$ \\
\hline \multicolumn{3}{|c|}{ Total } & $4.629,90$ \\
\hline
\end{tabular}

Gambar 21. Mengambil $V$ Belt 2

\begin{tabular}{|c|l|c|c|}
\hline No & \multicolumn{1}{|c|}{ Elemen Gerakan } & Notasi & $\begin{array}{c}\text { Waktu } \\
\text { (TMU) }\end{array}$ \\
\hline 1 & Gerakan mata untuk mencari sparepart & ET & 20,00 \\
\hline 2 & Menjangkau sparepart dengan jarak 30 inch & R30B & 25,80 \\
\hline 3 & Memegang sparepart & G1A & 2 \\
\hline 4 & Membawa sparepart dengan jarak 22 inch & M22C & 0 \\
\hline 5 & $\begin{array}{l}\text { Gerakan mata untuk melihat apakah sparepart yang } \\
\text { diambil benar }\end{array}$ & EF & 0 \\
\hline 6 & $\begin{array}{l}\text { Membawa sparepart ke mesin yang akan diperbaiki dengan } \\
\text { jarak 5382 inch dan berat sparepart kurang dari 7,5 pound } \\
\text { atau 3.401,943 gram }\end{array}$ & M5382C & $4.582,1$ \\
\hline \multicolumn{3}{|c|}{ Total } & $4.629,90$ \\
\hline
\end{tabular}

Gambar 23. Mengambil Pneumatic 2

\begin{tabular}{|c|l|c|c|}
\hline No & \multicolumn{1}{|c|}{ Elemen Gerakan } & Notasi & $\begin{array}{c}\text { Waktu } \\
\text { (TMU) }\end{array}$ \\
\hline 1 & Gerakan mata untuk mencari sparepart & ET & 15,20 \\
\hline 2 & Menjangkau sparepart dengna jarak 30 inch & R30B & 25,80 \\
\hline 3 & Memegang sparepart & G41 & 2,00 \\
\hline 4 & Membawa sparepart dengan jarak 19 inch & M19A & \\
\hline 5 & $\begin{array}{l}\text { Gerakan mata untuk melihat apakah sparepart yang } \\
\text { diambil benar }\end{array}$ & EF & \\
\hline 6 & $\begin{array}{l}\text { Membawa sparepart ke yang akan diperbaiki dengan jarak } \\
5382 \text { inch dan berat sparepart kurang dari 2,5 pound atau } \\
1.133,981 \text { gram }\end{array}$ & M5382C & $4.579,90$ \\
\hline \multicolumn{2}{|c|}{ Total } & $4.622,90$ \\
\hline
\end{tabular}

Gambar 25. Mengambil Rubber Cutting

JRTI is licensed under Creative Commons AttributionNonCommercial-ShareAlike 4.0 International License 


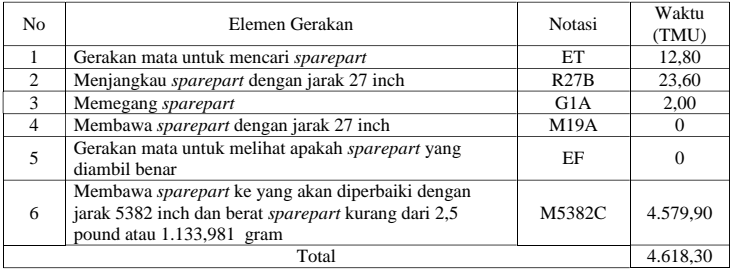

Gambar 26. Mengambil Folding Blade

\begin{tabular}{|c|l|c|c|}
\hline No & \multicolumn{1}{|c|}{ Elemen Gerakan } & Notasi & $\begin{array}{c}\text { Waktu } \\
\text { (TMU) }\end{array}$ \\
\hline 1 & Gerakan mata untuk mencari sparepart & ET & 10,40 \\
\hline 2 & Menjangkau sparepart dengna jarak 27 inch & R27B & 23,60 \\
\hline 3 & Memegang sparepart & G1A & 2,00 \\
\hline 4 & Membawa sparepart dengna jarak 27 inch & M19A & 0 \\
\hline 5 & $\begin{array}{l}\text { Gerakan mata untuk melihat apakah sparepart yang } \\
\text { diambil benar }\end{array}$ & EF & 0 \\
\hline 6 & $\begin{array}{l}\text { Membawa sparepart ke yang akan diperbaiki dengan jarak } \\
5382 \text { inch dan berat sparepart kurang dari 2,5 pound atau } \\
1.133,981 \text { gram }\end{array}$ & M5382C & $4.579,90$ \\
\hline \multicolumn{3}{|c|}{ Total } & $4.615,90$ \\
\hline
\end{tabular}

Gambar 28. Mengambil Cutting Knife

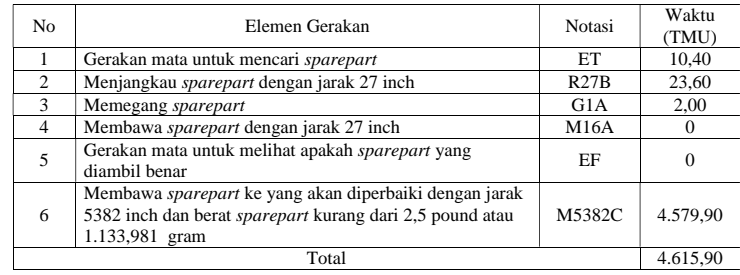

Gambar 27. Mengambil Tucker Blade

\section{Hasil Setelah Perbaikan}

Setelah dilakukan penerapan 5S, perhitungan waktu mengambil sparepart, dan waktumenunggu sparepart. Maka didapatkan hasil setelah perbaikan yang dapat dilihat pada Tabel 4.

Tabel 4. Rekapitulasi Waktu Hasil Perbaikan

\begin{tabular}{|c|l|c|c|c|}
\hline N & \multicolumn{1}{|c|}{ Aktivitas } & $\begin{array}{c}\text { Waktu Sebelum } \\
\text { Perbaikan (Menit) }\end{array}$ & $\begin{array}{c}\text { Waktu Setelah } \\
\text { Perbaikan (Menit) }\end{array}$ & $\begin{array}{c}\text { Waktu Yang } \\
\text { Direduksi (Menit) }\end{array}$ \\
\hline 1 & Mengambil Bearing & 60 & 2,78 & 57,22 \\
\hline 2 & Mengambil V Belt & 60 & 2,78 & 57,22 \\
\hline 3 & Mengambil Pneumatic & 60 & 2,78 & 57,22 \\
\hline 4 & Mengambil Relay & 60 & 2,78 & 57,22 \\
\hline 5 & Mengambil Rubber cutting & 60 & 2,77 & 57,23 \\
\hline 6 & Mengambil Folding Blade & 60 & 2,77 & 57,23 \\
\hline 7 & Mengambil Tucker Blade & 60 & 2,77 & 57,23 \\
\hline 8 & Mengambil Cutting Knife & 60 & 2,77 & 57,23 \\
\hline 9 & Menunggu Sparepart & 2880 & 0 & 2880 \\
\hline
\end{tabular}

Selanjutnya dilakukan penilaian kembali untuk mengetahui persentase 5S setelah perbaikan. Skor total keseluruhan program $5 \mathrm{~S}$ dapat dihitung dengan menggunakan formulir skor program $5 \mathrm{~S}$ setelah perbaikan yang dapat dilihat pada Tabel 5.

Tabel 5. Formulir Skor 5S Setelah Perbaikan

\begin{tabular}{|c|c|c|c|c|c|c|}
\hline & $\begin{array}{l}\text { Pemberian skor untuk setiap pernyataan berdasarkan aplikasi: } 0-20 \%= \\
\text { skor } 1,21 \%-40 \%=\text { skor } 2,41 \%-60 \%=\text { skor } 3,61 \%-80 \%=\text { skor } \mathbf{4},\end{array}$ & \multicolumn{5}{|c|}{ Skor } \\
\hline No & Pernyataan & 1 & 2 & 3 & & 5 \\
\hline 1 & $\begin{array}{l}\text { Semua orang telah memberikan kontribusi terhadap proses red tagging } \\
\text { untuk menyingkirkan item-item yang tidak diperlukan }\end{array}$ & & & & & \\
\hline 2 & Semua orang telah mengikuti prosedur untuk melakukan proses 3S & & & v & & \\
\hline 3 & $\begin{array}{l}\text { Semua mesin dan peralatan ditempatkan atau disimpan pada tempat } \\
\text { yang telah ditentukan. Telah ada penunjukan personil secara formal } \\
\text { dari manajemen untuk bertanggung jawab memelihara mesin, } \\
\text { peralatan, dan tempat kerja }\end{array}$ & & & & & \\
\hline 4 & $\begin{array}{l}\text { Semua mesin, peralatan, dan tempat kerja tampak bersih dan } \\
\text { terpelihara dengan sangat baik dan teratur }\end{array}$ & & & & & \\
\hline 5 & $\begin{array}{l}\text { Terdapat } 5 \mathrm{~S} \text { visual board, poster-poster, dan bentuk-bentuk visual } \\
\text { lainnya yang memungkinkan semua orang mengetahui dan mengerti } \\
\text { tentang } 5 \mathrm{~S} \text { dalam organisasi }\end{array}$ & & & & & \\
\hline 6 & $\begin{array}{l}\text { Terdapat prosedur dan instruksi kerja tentang } 5 \mathrm{~S} \text { yang diperbaharui } \\
\text { secara berkala }\end{array}$ & & & & & \\
\hline
\end{tabular}


Tabel 5. Formulir Skor 5S Setelah Perbaikan (Lanjutan)

\begin{tabular}{|c|c|c|c|c|c|}
\hline & $\begin{array}{c}\text { Pemberian skor untuk setiap pernyataan berdasarkan aplikasi: } 0-20 \%= \\
\text { skor } 1,21 \%-40 \%=\text { skor } 2,41 \%-60 \%=\text { skor } 3,61 \%-80 \%=\text { skor } \mathbf{4}, \\
81 \%-100 \%=\text { skor } \mathbf{5}\end{array}$ & \multicolumn{4}{|c|}{ Skor } \\
\hline No & Pernyataan & 1 & $\begin{array}{lll}23 \\
\end{array}$ & 4 & 5 \\
\hline 7 & $\begin{array}{l}\text { Semua karyawan dan manajemen telah memperoleh pelatihan secara } \\
\text { formal tentang } 5 \mathrm{~S} \text { agar memahami tentang prinsip } 5 \mathrm{~S}\end{array}$ & & & & \\
\hline 8 & $\begin{array}{l}\text { Terdapat sistem penghargaan dan pengakuan yang berlaku secara } \\
\text { formal sebagai alat motivasi dalam implementasi } 5 \mathrm{~S}\end{array}$ & & & & \\
\hline 9 & $\begin{array}{l}\text { Terdapat sistem audit } 5 \mathrm{~S} \text { yang dilakukan secara berkala. Skor audit } \\
\text { dikomunikasikan secara visual melalui } 5 \mathrm{~S} \text { visual board. Terdapat } \\
\text { personil atau bagian audit } 5 \mathrm{~S} \text { yang bertanggung jawab secara formal } \\
\text { dalam organisasi }\end{array}$ & & & & \\
\hline & SKOR TOTAL & & 33 & & \\
\hline & Maksimum Skor Total = 45 & & Skor & $5 \mathrm{~S}$ & \\
\hline & SKOR Program 5S $(\%)=(N / 45) \times 100$ & & 73 & & \\
\hline & $\begin{array}{l}\text { a Evaluasi Program 5S (Skor 5S): 0-20\% = Sangat Buruk, } 21 \%-40 \% \\
\mathbf{k}, 41 \%-60 \%=\text { Cukup, } 61 \%-80 \%=\text { Baik, } 81 \%-100 \%=\text { Sangat Baik }\end{array}$ & & & & \\
\hline
\end{tabular}

Berdasarkan hasil perhitungan pada Tabel 4.26, skor program 5S pada sistem penyimpanan sparepart setelah perbaikan mengalami kenaikan. Skor yang didapat yaitu $73 \%$. Berdasarkan kriteria evaluasi program 5S, skor 73\% persen ini termasuk kedalam kategori baik.

\section{Kesimpulan}

Berdasarkan pembahasan dalam penelitian ini, peneliti menyimpulkan beberapa hasil penelitian sebagai berikut:

1. Non value added activity yang ada pada sistem penyimpanan sparepart terdiri dari 2 waste, yaitu pemborosan menunggu (waste of waiting) dan pemborosan gerakan (waste of motion)

2. Non value added activity diatasi dengan penerapan $5 \mathrm{~S}$ (seiri, seiton, seiso, seiketsu, dan shitsuke) di perusahaan. Sehingga, rata-rata waktu mengambil diharapkan berkurang dari 60 menit menjadi 2,78 menit dan rata-rata waktu menunggu diharapkan berkurang dari 2880 menit menjadi 0 menit.

\section{Acknowledge}

Terima kasih kepada semua pihak yang telah memberikan dukungan dan doa untuk penulis, sehingga penelitian ini dapat terlaksana dan dapat diselesaikan dengan baik.

\section{Daftar Pustaka}

[1] Carreira, B., 2005. Lean Maufacturing That Works. [e-book] New York: American Management Association. Tersedia pada: <https://id.book4you.org> [Diakses 11 Agustus 2020].

[2] Imai, M., 2016. Kaizen. [e-book] Jakarta: Pustaka Binaman Pressindo.

[3] Matias, J.C.H. dan Idoipe, A.V., 2013. Lean Manufacturing, [e-book] Madrid: EOI.

[4] Osada, T., 1995. Sikap Kerja 5S. Jakarta: Pustaka Binaman Pressindo.

[5] PT X, 2018. Data Downtime Mesin. Bandung: PT X.

[6] Sutalaksana, I.Z., Anggawisastra, R., dan Tjakraatmadja, J.H., 2006. Teknik Perancagan Sistem Kerja. Bandung: Instritut Teknologi Bandung.

[7] Visco, D., 2016. 5S Made Easy: A Step-by-Step Guide to Implementing and Sustaining Your 5S Program. [e-book] Boca Raton: CRC Press. Tersedia pada: <https://id.book4you.org> [Diakses 16 Juli 2021]. 